\title{
Fate of Trace Organic Compounds in Hyporheic Zone Sediments of Contrasting Organic Carbon Content and Impact on the Microbiome
}

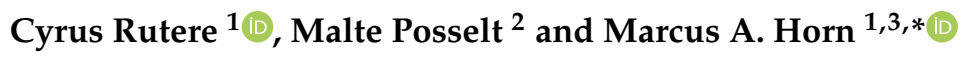 \\ 1 Department of Ecological Microbiology, University of Bayreuth, 95448 Bayreuth, Germany; \\ Cyrus.Njeru@uni-bayreuth.de \\ 2 Department of Environmental Science, Stockholm University, SE-106 91 Stockholm, Sweden; \\ Malte.Posselt@aces.su.se \\ 3 Institute of Microbiology, Leibniz University Hannover, 30419 Hannover, Germany \\ * Correspondence: horn@ifmb.uni-hannover.de; Tel.: +49-511-762-17980
}

Received: 15 November 2020; Accepted: 14 December 2020; Published: 15 December 2020

check for updates

\begin{abstract}
The organic carbon in streambed sediments drives multiple biogeochemical reactions, including the attenuation of organic micropollutants. An attenuation assay using sediment microcosms differing in the initial total organic carbon (TOC) revealed higher microbiome and sorption associated removal efficiencies of trace organic compounds (TrOCs) in the high-TOC compared to the low-TOC sediments. Overall, the combined microbial and sorption associated removal efficiencies of the micropollutants were generally higher than by sorption alone for all compounds tested except propranolol whose removal efficiency was similar via both mechanisms. Quantitative real-time PCR and time-resolved $16 \mathrm{~S}$ rRNA gene amplicon sequencing revealed that higher bacterial abundance and diversity in the high-TOC sediments correlated with higher microbial removal efficiencies of most TrOCs. The bacterial community in the high-TOC sediment samples remained relatively stable against the stressor effects of TrOC amendment compared to the low-TOC sediment community that was characterized by a decline in the relative abundance of most phyla except Proteobacteria. Bacterial genera that were significantly more abundant in amended relative to unamended sediment samples and thus associated with biodegradation of the TrOCs included Xanthobacter, Hyphomicrobium, Novosphingobium, Reyranella and Terrimonas. The collective results indicated that the TOC content influences the microbial community dynamics and associated biotransformation of TrOCs as well as the sorption potential of the hyporheic zone sediments.
\end{abstract}

Keywords: total organic carbon; trace organic compounds; hyporheic zone; sediments; amplicon sequencing; microbial diversity

\section{Introduction}

Wastewater-derived trace organic compounds (TrOCs) such as pharmaceuticals and personal care products are frequently detected in receiving rivers due to inefficient removal by most conventional treatment processes [1,2]. Despite occurring in trace concentration ranges (ng to $\left.\mu \mathrm{g} \mathrm{L}^{-1}\right)$, their persistence and accumulation are of ecotoxicological concern [3]. However, attenuation of such compounds via microbial transformation and sorption processes has been reported in the hyporheic zone, the saturated sediment directly beneath and lateral to the stream [2,4-6]. Both attenuation processes are significantly influenced by the organic matter content in the sediment since organic carbon fuels multiple TrOC-coupled biogeochemical reactions [7] as well as being the main sorbent for organic chemicals [8]. 
In impacted rivers and streams, most of the organic carbon derived from wastewater effluents, decomposing leaf litter and macrophytes is deposited onto the streambed sediment $[9,10]$. The upper section of the sediment or benthic zone as the primary contact point of such deposits has a higher concentration of organic carbon compared to subjacent layers [6,7]. Subsequently, most streambed sediments of receiving rivers are characterized by gradients in the organic carbon content along the depth profile. This bioavailable total organic carbon (TOC) is considered a major limiting factor for microbial metabolism [11]. As bacteria dominate microbial communities in streambed sediments [12-16], bacterial populations, turnover and metabolism are virtually higher in the surface sediment layer with corresponding mineralization rates decreasing exponentially with depth [6,17-19]. Additionally, as the main sorbent for organic chemicals, the decline in TOC content with increasing depth corresponds to reduced TrOC sorption potential of the sediment [16].

As rivers continue to be impacted by a wide range of emerging TrOCs, the influence of the hyporheic zone sediment TOC content on their removal becomes increasingly important. We hypothesized that hyporheic zone sediments differing in the TOC content along the depth profile host distinct microbiomes and exhibit variable TrOC removal capacities. We investigated the removal efficiency of a set of 13 TrOCs routinely discharged by a wastewater treatment plant (WWTP) using impacted hyporheic zone sediments differing in the initial TOC content. The compounds included pharmaceuticals from various pharmacological classes including nonsteroidal anti-inflammatory drugs (NSAIDs; diclofenac, ibuprofen, ketoprofen and naproxen), beta-blockers (metoprolol, propranolol), cholesterol-lowering agents (bezafibrate, clofibric acid), antihypertensive drugs (furosemide, hydrochlorothiazide), anticonvulsant (carbamazepine), an artificial sweetener (acesulfame), and a corrosion inhibitor (benzotriazole).

Our objectives were to (i) determine TrOC removal efficiencies in hyporheic zone sediments differing in initial TOC concentrations via microbial transformation and sorption mechanisms, (ii) assess the response of the indigenous bacterial communities in the sediments differing in TOC concentrations to TrOC amendment, and (iii) hence identify potential bacterial TrOC degraders. To address our aims, we (i) performed a TrOC attenuation assay in biotic and abiotic batch microcosms, and (ii) characterized the response of the indigenous bacterial community using time-resolved high-throughput sequencing of the 16S rRNA genes and 16S rRNA.

\section{Materials and Methods}

\subsection{Study Site and Sampling}

Sediment samples were collected from a section of the River Erpe, an urban lowland stream in Berlin, Germany, located approximately $0.7 \mathrm{~km}$ downstream of the Muenchehofe WWTP effluent outlet. The stream receives $60-80 \%$ of its discharge as effluents [20]. In June 2016, the site was selected for a comprehensive study on the fate of TrOCs in the hyporheic zone. The sediments at the sampling site were densely covered by macrophytes, hence minimizing light exposure onto the surface sediment [20]. Preliminary analysis of the nutrient species across the sediment profile indicated the upper $30 \mathrm{~cm}$ was oxic [6]. The sediment was also virtually homogenous up to about $35 \mathrm{~cm}$ depth and consisted mainly of sand $(>50 \%)$, silt and gravel [21]. The sediment TOC concentration decreased with increasing depth. The upper layer $(0-10 \mathrm{~cm})$, hereafter referred to as the surface layer, and the subjacent layer ( $>10 \mathrm{~cm}$ of depth), hereafter referred to as the subsurface layer, contained $8.7 \%$ and $3.2 \%$ TOC, respectively [5], which was in a typical range of TOC found in temperate streambed environments (2.0-33\%; average: 8.5\%; [22]). Three sediment cores up to the $20 \mathrm{~cm}$ sediment depth were collected using $6 \mathrm{~cm}$-diameter sediment corers (Uwitec, Mondsee, Austria). Grab samples of the surface water were also collected at the same location as the sediment cores and stored in sealed bottles. The core samples were then transferred to the laboratory and sectioned in $10 \mathrm{~cm}$ intervals. Sediment samples between depths $0-10 \mathrm{~cm}$ and $10-20 \mathrm{~cm}$ from the three replicate cores were manually homogenized in sterile plastic containers using alcohol-sterilized spatulas and processed aerobically under standard 
sterile lab conditions. A portion ( $\mathrm{t} 0$ samples) from each sectioned depth was stored at $-80{ }^{\circ} \mathrm{C}$ for subsequent extraction of nucleic acids.

\subsection{Chemicals and Standards}

Native and isotope-substituted internal standards of the test compounds-diclofenac, ibuprofen, ketoprofen, naproxen, metoprolol, propranolol, bezafibrate, clofibric acid, furosemide, hydrochlorothiazide, carbamazepine, benzotriazole and acesulfame-were purchased from Toronto Research Chemicals Inc., (North York, ON, Canada). Liquid chromatography-mass spectrometry (LC-MS) grade methanol was purchased from Merck (Darmstadt, Germany), analytical grade acetic acid ( $\geq 99.7 \%$ ) from Sigma-Aldrich (Darmstadt, Germany) and LC-MS grade water was generated with a Milli-Q water purification system (Merck, Darmstadt, Germany). Stock and working solutions were prepared as reported in [4].

\subsection{Microcosm Setup}

Three sets of microcosms per sediment layer using duplicate samples for each of the three sediment cores were set up in $5 \mathrm{~mL}$ glass bottles, each containing $2 \mathrm{~g}$ of wet sediment and $2 \mathrm{~mL}$ of river water. In total, nine microcosms were set up per sediment layer $(3 \times$ sediments from three cores 3). In two of the three sets, the river water was amended with approximately $500 \mu \mathrm{g} \mathrm{L}^{-1}$ of each of the 13 test compounds. All 13 test TrOCs occur at the sampling site, and TrOCs typically range from 0.1 to $200 \mu \mathrm{g} \mathrm{L}{ }^{-1}$ in surface and hyporheic pore waters [4]. TrOC concentrations applied in our microcosms were higher but in the same order of magnitude of concentrations observed in situ [4]. Such high concentrations were used to allow for an enrichment of potential TrOC degraders as previously demonstrated $[23,24]$. To account for sorption, one of the setups was treated with $0.1 \%$ sodium azide to reduce bacterial activity. The third set of microcosms served as an unamended biotic control and was incubated without the test compounds. The slurries were then thoroughly mixed, and the bottles capped. All setups were incubated at $18{ }^{\circ} \mathrm{C}$ with shaking at 100 rotations per minute for the duration of the test to facilitate water infiltration in the sediments. Incubation was in the dark to mimic light-limited conditions of sediments due to macrophyte coverage of sediments, and to minimize potential photolysis. The microcosms were aerated daily under sterile conditions. After 15 days of incubation, three replicates from each treatment were destructively sampled, and the sediment from the biotic setups stored at $-80^{\circ} \mathrm{C}$ for subsequent nucleic acid extraction. At the end of the test (65 days), the supernatant was withdrawn for LC-MS analysis of the test compounds and the sediment used for nucleic acid extraction.

\subsection{Chemical Analysis}

Water samples were analyzed using a direct injection-ultra high-performance liquid chromatography method coupled to tandem mass spectrometry (UHPLC-MS/MS) following a standard protocol established previously [4]. Frozen water samples $\left(-20^{\circ} \mathrm{C}\right)$ were equilibrated to room temperature, and volumes of $800 \mu \mathrm{L}$ were combined with $195 \mu \mathrm{L}$ methanol and the isotope-labeled internal standard mix in $5 \mu \mathrm{L}$ methanol. The mixture was then vortexed and filtered using Filtropur $S$ $0.45 \mu \mathrm{m}$ polyethersulfone (PES) membrane syringe filters (Merck, Sarstedt, Germany) into $2 \mathrm{~mL}$ micro vials (Thermo Scientific, Dreieich, Germany). The UHPLC-MS/MS injection volume was $20 \mu \mathrm{L}$. A blank sample to control for carry-over and a quality control standard (QC, compound concentration 0.5-3 $\mu \mathrm{g} \mathrm{L}^{-1}$ ) was injected every 10-15 samples. The acquired MS data were further processed using Thermo Scientific Xcalibur 3.1.66.10 software and quantified using the internal standards method [4]. The removal efficiency of the test compounds was calculated as a percentage of the initial spiked concentration. 


\subsection{Nucleic Acid Extraction, Quantification, and Reverse Transcription}

DNA and RNA were co-extracted following the rapid protocol for the extraction of total nucleic acids from environmental samples [25]. The nucleic acids were subsequently separately obtained through enzymatic digestion using DNase-free RNase and RNase-free DNase (Promega, Mannheim, Germany), respectively, according to the manufacturer's instructions. DNA and RNA concentrations were determined with Quant-iT ${ }^{\circledR}$ PicoGreen DNA and RiboGreen RNA assay kits (Invitrogen, Karlsruhe, Germany), respectively, using a Tecan Infinite ${ }^{\circledR} 200$ PRO multiplex plate reader (BioTek, Bad Friedrichshall, Germany). The RNA was subsequently reverse transcribed into complementary DNA (cDNA) using random hexamer primers and Superscript ${ }^{\mathrm{TM}}$ IV Reverse Transcriptase (Invitrogen, Mannheim, Germany) following the manufacturer's protocol.

\subsection{Quantitative Real-Time PCR}

The bacterial 16S rRNA gene and 16S rRNA copy numbers were quantified using the quantitative real-time polymerase chain reaction (qPCR). The nucleic acids were first diluted 100-fold to reduce potential inhibition of qPCR by coextracted PCR-inhibiting compounds and confirmed inhibition-free at such dilutions using spiking assays as described in Zaprasis et al. [26]. The qPCR reaction mixture

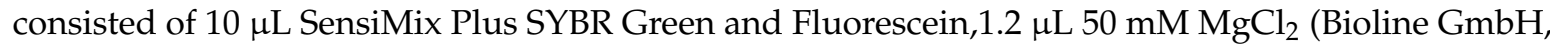
Luckenwalde, Germany), $150 \mathrm{ng} / \mu \mathrm{L}$ bovine serum albumin, 0.2-1.6 pM of each primer (341F/534R) (Biomers, Ulm, Germany), $5 \mu \mathrm{L}$ template (DNA or cDNA) and nuclease-free water (Thermo Fischer Scientific, Dreieich, Germany). The thermal cycling program comprised initial denaturation at $95^{\circ} \mathrm{C}$ for $10 \mathrm{~min}$, and 35 cycles of denaturation at $94{ }^{\circ} \mathrm{C}$ for $30 \mathrm{~s}$, primer annealing at $55.7{ }^{\circ} \mathrm{C}$ for $40 \mathrm{~s}$ and elongation at $72{ }^{\circ} \mathrm{C}$ for $40 \mathrm{~s}$. The final elongation was at $72{ }^{\circ} \mathrm{C}$ for $5 \mathrm{~min}$.

\subsection{Bacterial $16 S$ Amplicon Sequencing}

Sequencing of the bacterial 16S rRNA genes and 16S rRNA was implemented via Miseq ${ }^{\circledR}$ Illumina ${ }^{\circledR}$ platform at LGC Genomics GmbH (Berlin, Germany). An initial PCR amplification step (protocol kindly provided by LGC), consisted of $1 \times$ MyTaq buffer containing 1.5 units MyTaq DNA polymerase (Bioline, London, UK) and $2 \mu \mathrm{L}$ of BioStabII PCR Enhancer (Sigma-Aldrich, Darmstadt, Germany), 15 pmol of each forward primer U341F and reverse primer U806R [27] and $5 \mathrm{ng}$ of DNA/cDNA per sample in nuclease-free water (Thermo Fischer Scientific, Dreieich, Germany) in a final $20 \mu \mathrm{L}$ volume. For each sample, the forward and reverse primers had the same $10 \mathrm{nt}$ barcode sequence. The PCR was carried out using the following thermal profile: $2 \mathrm{~min}$ at $96{ }^{\circ} \mathrm{C}$ initial denaturation followed by 30 cycles of $96^{\circ} \mathrm{C}$ for $15 \mathrm{~s}, 50{ }^{\circ} \mathrm{C}$ for $30 \mathrm{~s}$ and final elongation at $70{ }^{\circ} \mathrm{C}$ for $90 \mathrm{~s}$. About $20 \mathrm{ng}$ amplicon DNA of each sample was pooled for up to 48 samples with different barcodes. If needed, PCRs showing low yields were further amplified for five cycles. The amplicon pools were purified with one volume Agencourt AMPure XP beads (Beckman Coulter, CA, USA) to remove primer dimers, followed by an additional purification on MinElute columns (Qiagen, Hilden, Germany). About 100 ng of each purified amplicon pool DNA was used to construct Illumina sequencing libraries using the Ovation Rapid DR Multiplex System 1-96 (NuGEN, Leek, The Netherlands). Illumina libraries were pooled and size selected by preparative gel electrophoresis. Sequencing was performed on an Illumina MiSeq using V3 Chemistry (Illumina, CA, USA) yielding 300 base paired-end reads.

Raw amplicon sequences were analyzed by demultiplexing all libraries using the Illumina bcl2fastq 1.8.4 software. The reads were sorted by amplicon inline barcode corresponding to independent samples followed by trimming of sequencing adapters and primers. Combination of forward and reverse reads was performed using BBMerge 34.38. Using Mothur 1.35.1 [28], sequences containing ambiguous bases (Ns), with homopolymer stretches of more than 8 bases or with an average Phred quality score below 33 were removed. Remaining sequences were aligned against the 16S Mothur-Silva SEED r119 reference alignment followed by sequence subsampling. Errors in sequences were reduced by preclustering, while chimeras were eliminated with the uchime algorithm. This was followed by 
taxonomical classification of the sequences (against the Silva reference classification) and removal of sequences from other domains of life. Operational taxonomic unit (OTU) picking by clustering at the $97 \%$ identity level (using the cluster.split method) and OTU consensus taxonomical calling, integrating the taxonomical classification of the cluster member sequences were then performed. The representative sequences of each OTU (with at least 2 observed sequences) were queried against a filtered (unknown and unclassified sequences were removed) version of the ribosomal database project release 11.4 reference, and a summary table with taxonomy and alignment details for each OTU representative sequence was generated. OTU relative abundance data filtered for low-abundance OTUs were subsequently generated with QIIME 1.9.0 using rarified data based on the sample with the minimum number $(12,805)$ of sequences. Please note that Silva r119 used in the current study classifies the "Betaproteobacteria" as "Betaproteobacteriales", an order of the Gammaproteobacteria. Thus, genera and higher taxonomic ranks that formerly represented "Betaproteobacteria" now belong to "Gammaprotobacteria".

Sequence data were deposited in the NCBI Sequence Read Archive under the accession number PRJNA633609.

\subsection{Statistical Analyses}

ANOVA and Tukey's test ( $p$-value of $<0.05$ ) were used to evaluate statistically significant differences in the removal efficiencies of the test compounds, the effect of treatments on the total bacteria $16 \mathrm{~S}$ rRNA copy numbers as well as the alpha diversity indices using PAST v3.15 [29]. Principal coordinate analysis (PCOA) plots and a two-way analysis of similarity (ANOSIM) based on the Bray-Curtis metric were used to visualize bacterial community composition and to test for significant differences among the treatments, respectively, using PAST v3.15. OTUs with significant differential abundance between treatments were identified using the DESeq2-function in R [30], performed on the non-rarefied, non-normalized datasets using Benjamin-Hochberg adjusted significance levels $(p$-adj < 0.05).

\section{Results}

\subsection{Depletion of TrOCs under Varying TOC Concentrations}

Depletion of TrOCs in the biotic microcosm setups with initially high (8.7\%) and low (3.2\%) TOC concentrations varied considerably within and among test compound classes (Figure 1A). Among the NSAIDs, the removal efficiencies of ibuprofen and ketoprofen were 2-fold higher in the surface relative to subsurface samples. Diclofenac removal efficiency was only marginally higher in the surface compared to the subsurface sediment samples, while naproxen was removed entirely under both TOC conditions. Among the beta-blockers, complete removal of propranolol was observed under both TOC conditions, while metoprolol removal was only marginally higher in the surface relative to subsurface layer samples. The cholesterol-lowering agents bezafibrate and clofibric acid removal correlated with the TOC concentration with significantly higher removal efficiency observed in the surface sediment layer. However, clofibric acid exhibited relative persistence in both TOC conditions with only less than 50\% removed. Significantly higher removal also occurred for carbamazepine, benzotriazole and acesulfame but not for furosemide and hydrochlorothiazide in the surface relative to subsurface sediment samples.

In the abiotic setups, sorption of TrOCs to the sediment correlated with the initial sediment TOC concentration for most compounds (Figure 1B). Among the NSAIDs, the removal efficiencies of diclofenac, ketoprofen and naproxen were significantly higher in the surface compared to subsurface sediment, while that of ibuprofen was only marginally higher. Similar to the biotic setups, the removal of the beta-blockers metoprolol and propranolol was high under both TOC conditions. Propranolol was removed entirely, while metoprolol removal exceeded $80 \%$ under both high and low TOC conditions. Significantly higher removal efficiency was also observed for bezafibrate, carbamazepine and benzotriazole but not for clofibric acid in the surface relative to subsurface samples. Acesulfame 
removal did not occur in abiotic setups under both high and low TOC conditions. On the other hand, furosemide exhibited a significantly higher removal efficiency in the subsurface relative to surface samples.

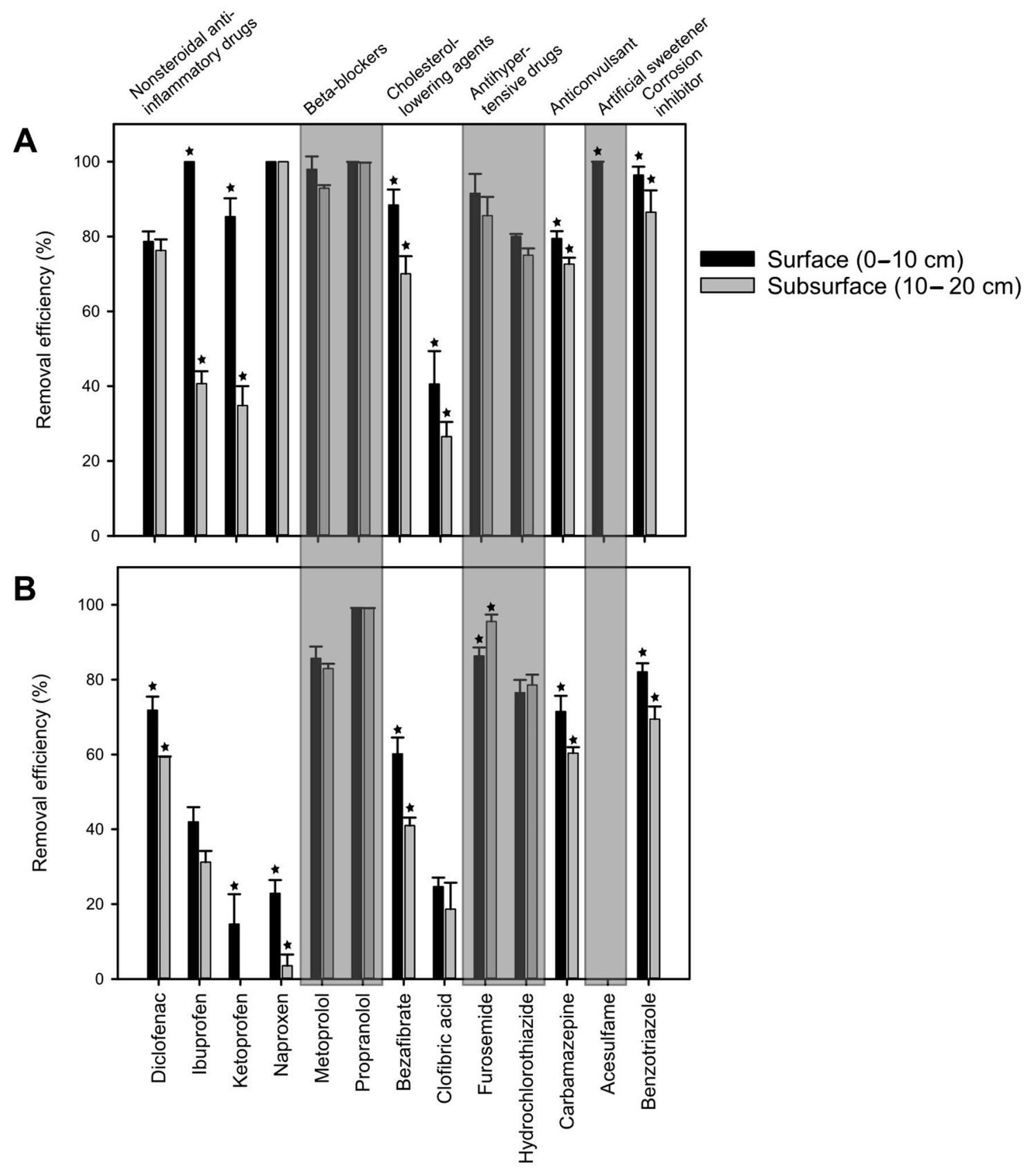

Figure 1. Relative removal efficiency of test compounds in the (A) biotic and (B) abiotic (azide-inhibited, sorption) batch microcosms containing surface and subsurface sediment samples after 65 days of incubation. Values are the arithmetic means of triplicate incubations. Error bars indicate standard deviations. Some standard deviations are smaller than the symbol size and, therefore, not apparent. Asterisks $\left(^{*}\right)$ indicate significant differences in removal efficiency between surface and subsurface sediment samples (ANOVA, $p<0.05$ ). Compound groups are indicated above panel A.

Overall, the removal efficiency of most test compounds was higher via biotic and abiotic mechanisms in the surface relative to subsurface sediment samples (Figure 1). However, a comparison between the two mechanisms revealed significantly higher removal of ibuprofen, ketoprofen, naproxen, 
metoprolol, bezafibrate, clofibric acid, carbamazepine, acesulfame and benzotriazole in the biotic relative to abiotic treatments of surface sediment samples. In the subsurface samples, the compounds diclofenac, ketoprofen, naproxen, metoprolol, bezafibrate, carbamazepine and benzotriazole registered significantly higher removal efficiencies in the biotic relative to abiotic samples.

\subsection{Effect of Treatments on Bacterial Community Structure and Composition}

\subsubsection{The Abundance of the Total Bacterial Community}

The unincubated sediment samples, i.e., t0 samples, revealed approximately $10^{9} 16 \mathrm{~S}$ rRNA gene and $16 \mathrm{~S}$ rRNA copies per gram sediment (Figure 2). Following incubation, a marginal decline occurred in the 16S rRNA gene copies in both amended and unamended surface sediment samples, while a significant decline occurred in the subsurface samples (ANOVA, $p<0.05$ ), compared to corresponding t0 samples. TrOC-amended surface sediment samples registered higher 16S rRNA gene and 16S rRNA copies than the unamended samples analyzed at days 15 and 65 (Figure 2A). On the other hand, the $16 \mathrm{~S}$ rRNA gene copies in the subsurface samples were marginally lower in amended relative to unamended samples on day 15 but higher at day 65 (Figure 2B). The 16S rRNA copies were, however, marginally higher in the amended than unamended samples at both days 15 and 65 .
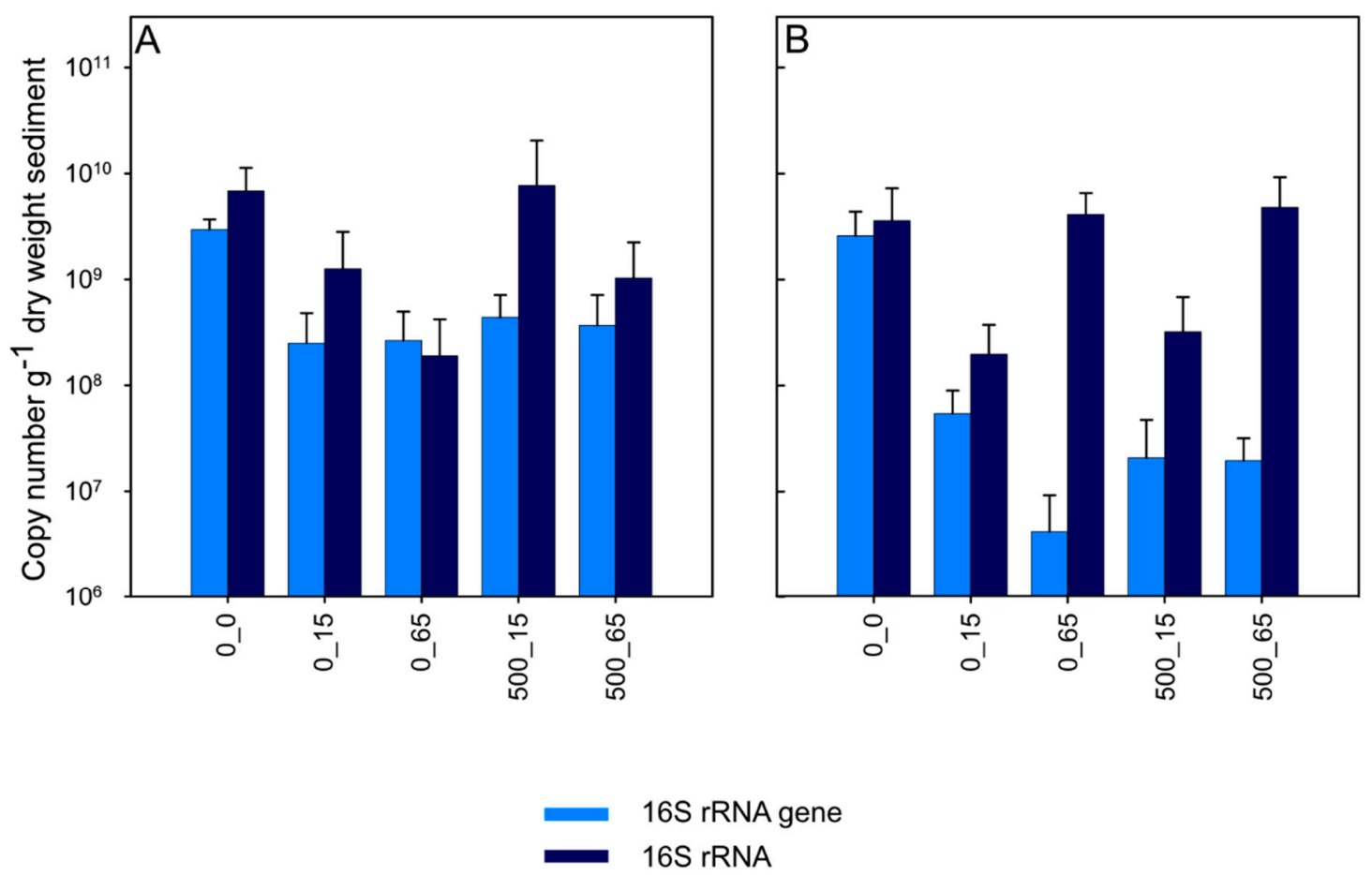

Figure 2. Abundance (copy numbers) of bacterial 16S rRNA genes and 16S rRNA detected in oxic hyporheic zone microcosms containing (A) surface and (B) subsurface sediment samples. Sample code: 0, 500 indicate supplemental TrOC concentrations in $\mu \mathrm{g} \mathrm{L}^{-1}$. 0, 15, 65 represent sampling days. Values are the arithmetic means of triplicate incubations. Error bars indicate standard deviations.

\subsubsection{Diversity and Bacterial Community Structure}

Surprisingly, species richness was higher in the subsurface than surface sediment samples in the sediment prior to incubation (Figure 3A,B). However, a significantly higher species richness was observed in the amended surface compared to subsurface samples obtained at days 15 and 65 following incubation. In contrast, higher species richness was observed in the unamended subsurface relative to surface samples at day 65 . 

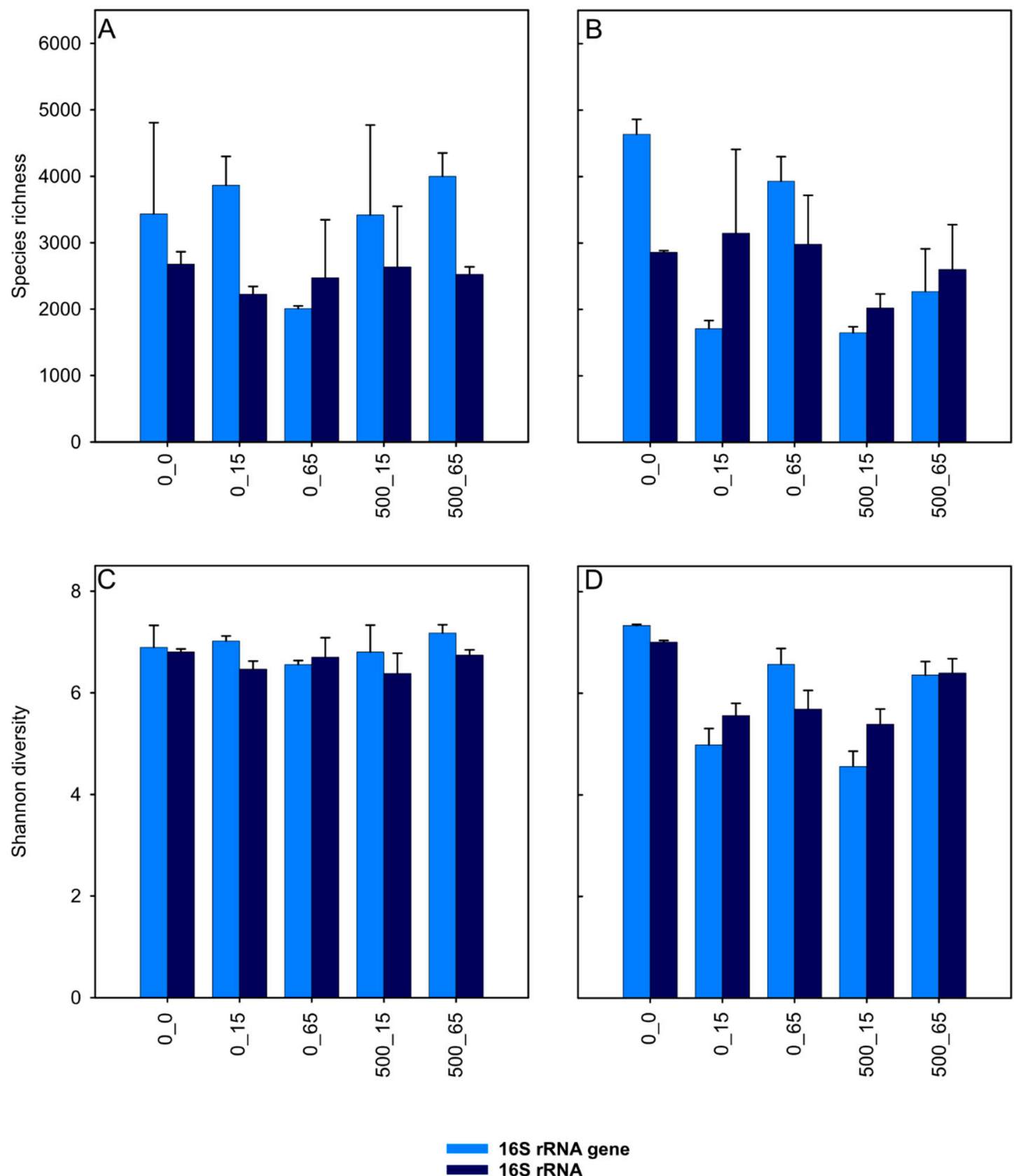

Figure 3. Taxa richness $(\mathbf{A}, \mathbf{B})$ and Shannon diversity $(\mathbf{C}, \mathbf{D})$ of the total bacterial community in surface $(\mathbf{A}, \mathbf{C})$ and subsurface (B,D) sediment samples. Sample code: 0,500 indicate supplemental TrOC concentrations in $\mu \mathrm{g} \mathrm{L}^{-1}$. 0,15,65 represent sampling days. Values are the arithmetic means of triplicate incubations. Error bars indicate standard deviations.

The Shannon diversity was likewise marginally higher in the unincubated (t0) subsurface relative to surface samples (Figure 3C,D). However, in incubated samples, the surface samples exhibited higher diversity indices compared to the subsurface samples irrespective of treatment.

PCoA plots based on 16S rRNA gene and 16S rRNA sequence data, and ANOSIM R-values, revealed the effect of the treatments on the microbial community. R-values greater than 0.6 indicated a rather strong dissimilarity between microbial communities from different treatments and time points. In the surface sediment samples, the PCoA plots revealed distinct clustering of the bacterial community according to incubation time, while the effect of TrOC amendment was not apparent (Figure 4A,B). Consistent with these findings, the two-way ANOSIM test indicated that in the 
surface sediment samples, incubation time accounted significantly for the variation in the bacterial community composition (DNA: $\mathrm{R}=0.7$, RNA: $\mathrm{R}=0.7, p<0.02$ ), while the effect of treatments was not apparent (DNA: $\mathrm{R}=0.3$, RNA: $\mathrm{R}=0.2, p<0.22$ ). For the subsurface samples, both incubation time and TrOC amendment contributed significantly to the differences in the bacterial community composition. The clustering, however, distinctly separated along axis 1, depicting a stronger influence of incubation time than that of the TrOC amendment (Figure 4C,D). The corresponding ANOSIM test further supported this observation by revealing the stronger effect of incubation time (DNA: $R=0.9$, RNA: $\mathrm{R}=0.9, p<0.02$ ) compared to TrOC amendment (DNA: $\mathrm{R}=0.7$, RNA: $\mathrm{R}=0.7, p<0.01$ ).
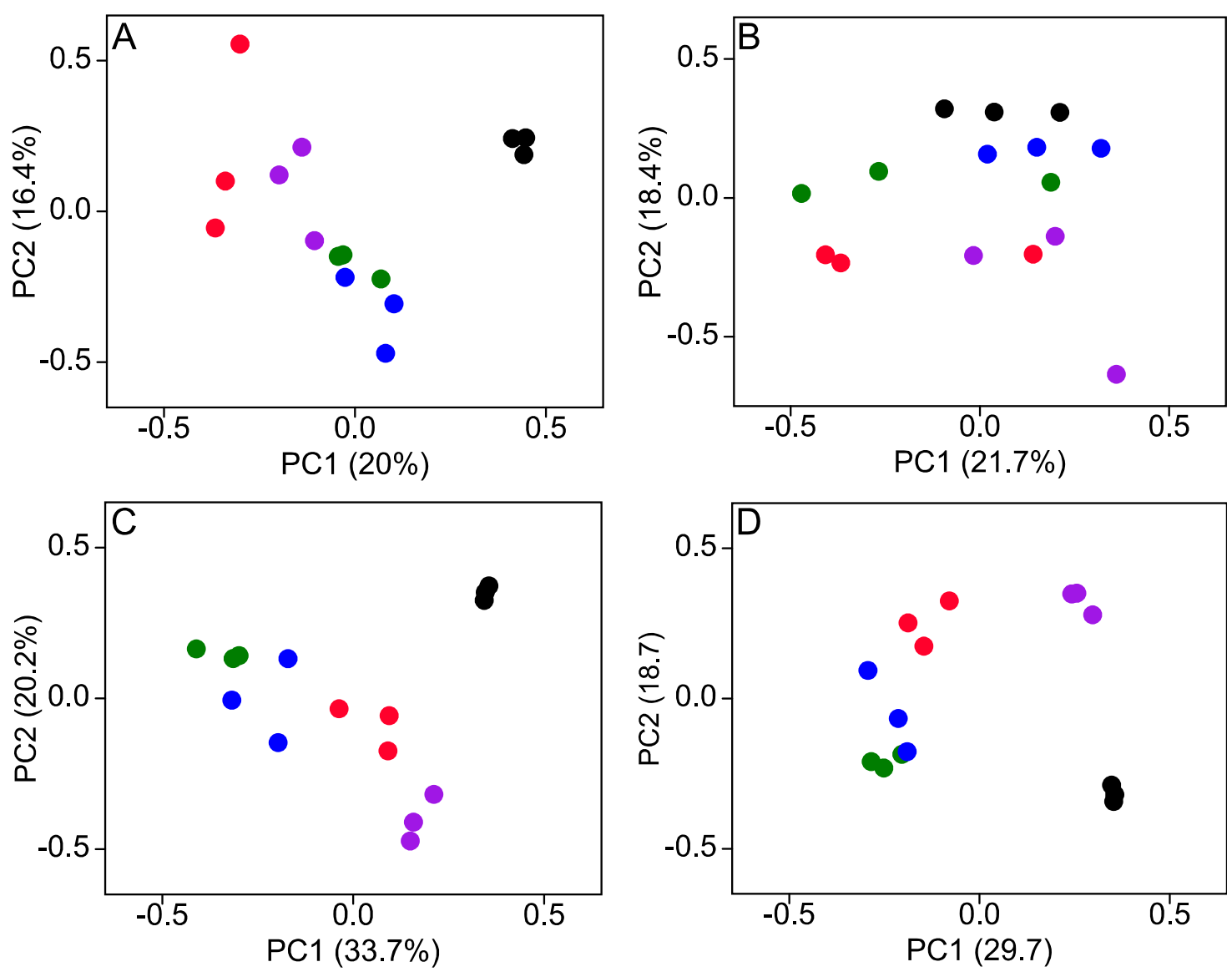

$$
\begin{array}{ll}
\text { - } & \text { 0_0 } \\
\text { - } & \text { 0_15 } \\
\text { - } & \text { 0_65 } \\
\text { - } & \text { 500_15 } \\
\text { - } & \text { 500_65 }
\end{array}
$$

Figure 4. Principal coordinate analysis based on Bray-Curtis dissimilarity metric showing the effect of TrOCs on the bacterial community composition on operational taxonomic unit (OTU)-level from 16S rRNA gene $(\mathbf{A}, \mathbf{C})$ and $16 \mathrm{~S}$ rRNA $(\mathbf{B}, \mathbf{D})$ data for surface $(\mathbf{A}, \mathbf{B})$ and subsurface $(\mathbf{C}, \mathbf{D})$ sediment samples, respectively. Sample code: 0,500 indicate supplemental $\operatorname{TrOC}$ concentrations in $\mu \mathrm{g} \mathrm{L}^{-1}$. 0, 15, 65 represent sampling days. 


\subsubsection{Phylum-Level Taxonomic Composition}

The predominant phyla in the two sediment layers on DNA and RNA levels were Proteobacteria, Chloroflexi, Actinobacteria, Acidobacteria, Bacteroidetes and Firmicutes (Figure 5). Other phyla identified ( $>1 \%$ relative abundance) included Nitrospirae, Gemmatimonadetes and Chlorobi. The t0 samples indicated that only the relative abundance of the predominant phylum Proteobacteria was higher in the surface (38\%) compared to the subsurface layer (32\%), while other phyla were similar in terms of relative abundance in the two layers.
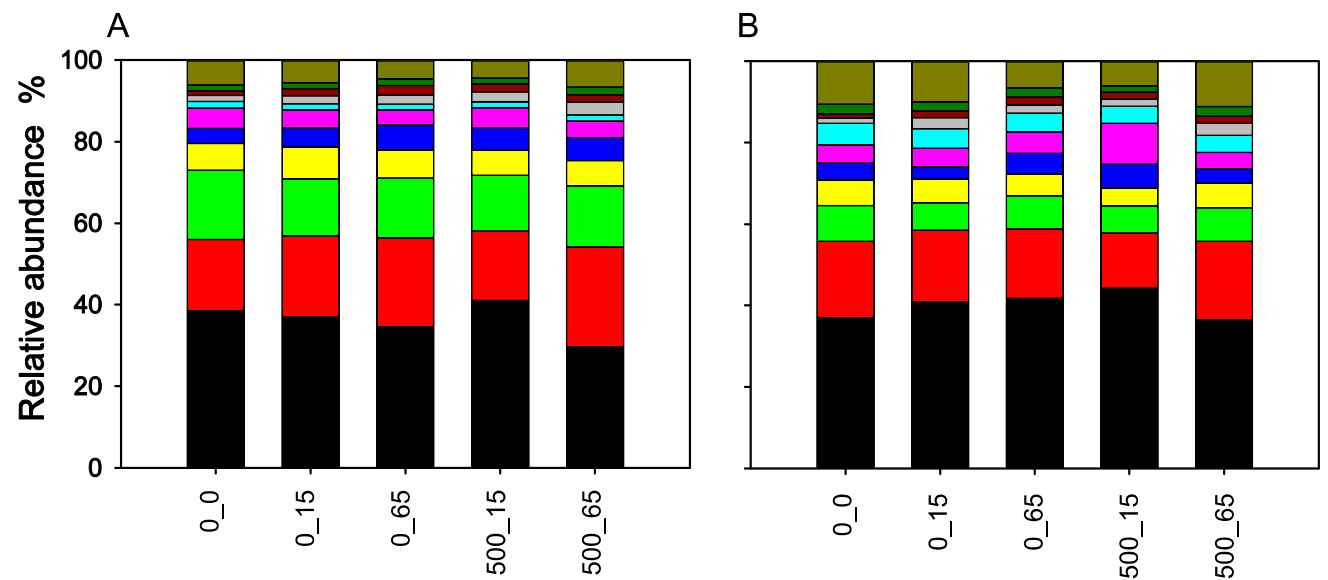

C

$\mathrm{D}$
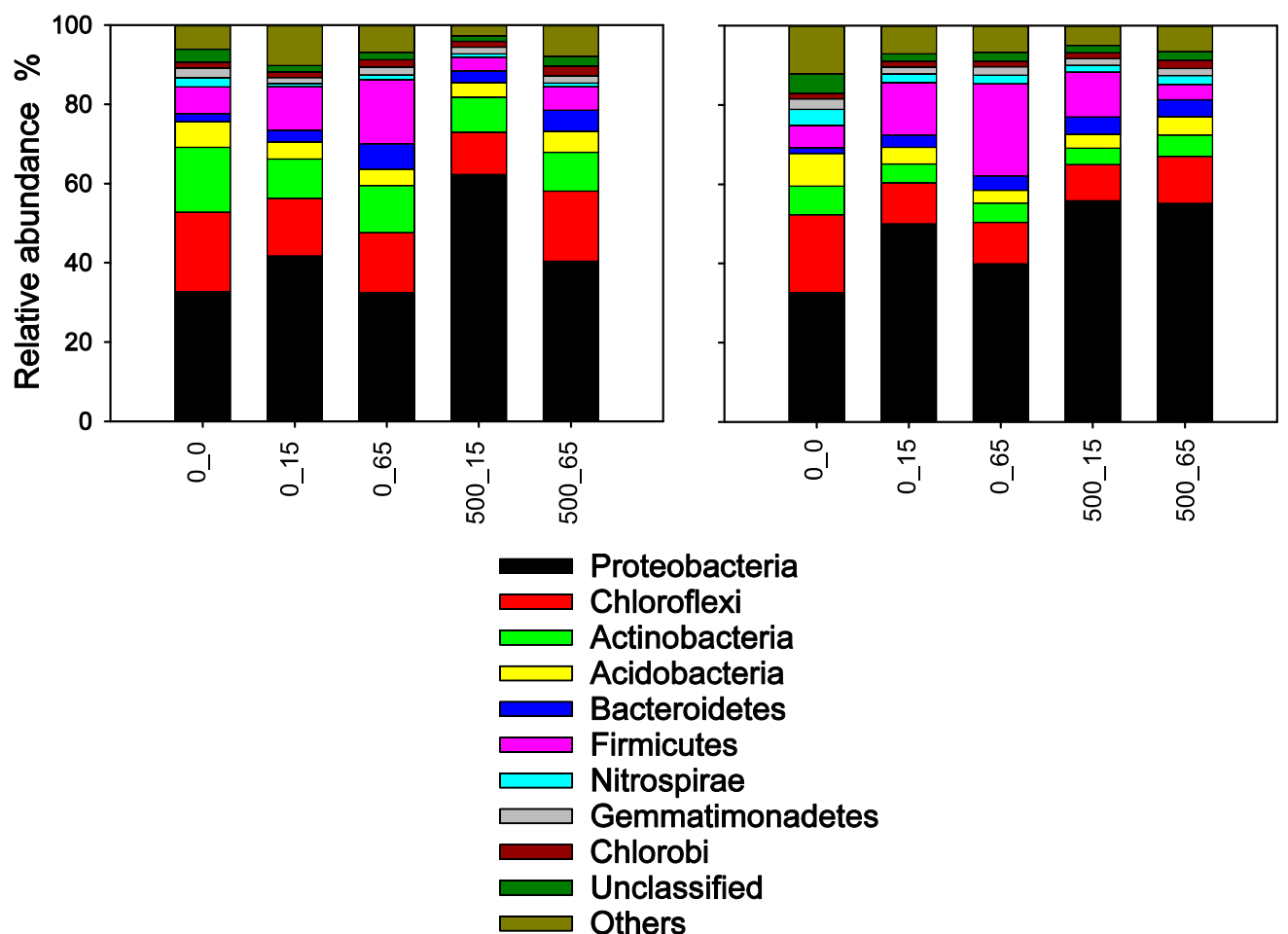

Figure 5. Mean relative abundance of major bacterial phyla ( $>1 \%$ relative abundance) on $16 \mathrm{~S}$ rRA gene $(\mathbf{A}, \mathbf{C})$ and 16S rRNA (B,D) level for surface (A,B) and subsurface $(\mathbf{C}, \mathbf{D})$ sediment samples. Phyla accounting for less than $1 \%$ of all sequences are grouped as "others". Sample code: 0, 500 indicate supplemental TrOC concentrations in $\mu \mathrm{g} \mathrm{L}^{-1}$. 0, 15, 65 represent sampling days.

Following incubation, amended relative to unamended surface sediment samples registered an increase in the relative abundance of some phyla at day 15 (Figure 5A,B). These included Proteobacteria 
(DNA: 37 to 41\%, RNA: 40 to $44 \%$ ), Bacteroidetes (DNA: 4.5 to 5.5\%, RNA: 3 to 6\%) and Firmicutes (DNA: 4 to 5\%; RNA: 5 to 10\%). Chloroflexi (DNA: 22 to 25\%, RNA: 17 to $20 \%$ ) and Gemmatimonadetes (DNA: 2 to 3\%, RNA: 2 to 3\%) increased in the relative abundance at day 65 .

In the subsurface samples (Figure 5C,D), an increase in the relative abundance in amended relative to unamended samples at day 15 occurred only in Proteobacteria (DNA: 41 to 62\%, RNA: 49 to 56\%), while other phyla declined including Chloroflexi (DNA: 18 to 14\%, RNA: 15 to 11\%), Acidobacteria (DNA: 4 to 3\%, RNA: 4 to 3\%) and Firmicutes (DNA: 11 to 4\%, RNA: 13 to 11\%). At day 65, however, an increase in the relative abundance was observed in Proteobacteria (DNA: 32 to $40 \%$, RNA: 40 to 55\%), Chloroflexi (DNA: 15 to 18\%, RNA: 10 to 12\%) and Acidobacteria (DNA: 4 to 5\%, RNA: 3 to $5 \%$ ).

\subsubsection{Family-Level Taxonomic Composition}

The 0 surface and subsurface sediment samples exhibited a similar number of dominant bacterial families (>3\% relative abundance) at the DNA level (Figure 6A,C). However, the surface sediment samples had a higher number of dominant families than subsurface sediment samples at the RNA level (Figure 6B,D). These included Proteobacteria affiliated Hyphomicrobiaceae and Comamonadaceae; Caldilineaceae and unclassified families of JG30-KF-CM66, KD4-96, TK10, JG30-KF-CM45 belonging to the Chloroflexi; an Acidobacterial Subgroup 6 family, and Nitrospiraceae (Nitrospirae). Among the t0 samples, some families exhibited higher relative abundances in the subsurface than in surface sediment. These included the family Anaerolineaceae at the DNA and RNA levels, Rhodobiaceae at the DNA level and Gemmatimonadaceae at the RNA level (Figure 6).

Incubated surface sediment samples amended with TrOCs exhibited an increased relative abundance relative to unamended controls in the families Methylophilaceae, Caldilineaceae, Acidimicrobiaceae and Gemmatimonadaceae and an unclassified KD4-96 family at the DNA level (Figure 6A). At the RNA level, Methylophilaceae, Comamonadaceae, Anaerolineaceae, unclassified JG30-KF-CM45, Acidobacteria Subgroup 6 family and Eubacteriaceae were stimulated by the TrOCs (Figure 6B). The amended subsurface sediment samples exhibited higher relative abundance than the unamended controls in the families Xanthobacteriaceae, Hydrogenophiliaceae, Rhodospirillaceae, Methylophilaceae, Rhodocyclaceae and an unclassified KD4-96 family at both DNA and RNA levels, Hyphomicrobiaceae, Caldilineaceae, Acidobacteria Subgroup 6 family only at the DNA level and Comamonadaceae, Anaerolineaceae and Peptococcaceae at the RNA level, respectively (Figure 6C,D).

\subsubsection{Genus-Level Taxa Associated with TrOC Degrading Microbial Communities}

Relative to unamended controls, some specific taxa were considered enriched by the test compounds based on significant differential abundance as determined by Log2foldchange values (Table 1). Based on the 16S rRNA gene and 16S rRNA analyses, diverse taxa were enriched in response to TrOCs, including known and Candidatus genera affiliated with the phyla Proteobacteria (alpha-, delta-, gamma) and Bacteroidetes (Sphingobacteriia and Cytophagia) (Table 1). 
A
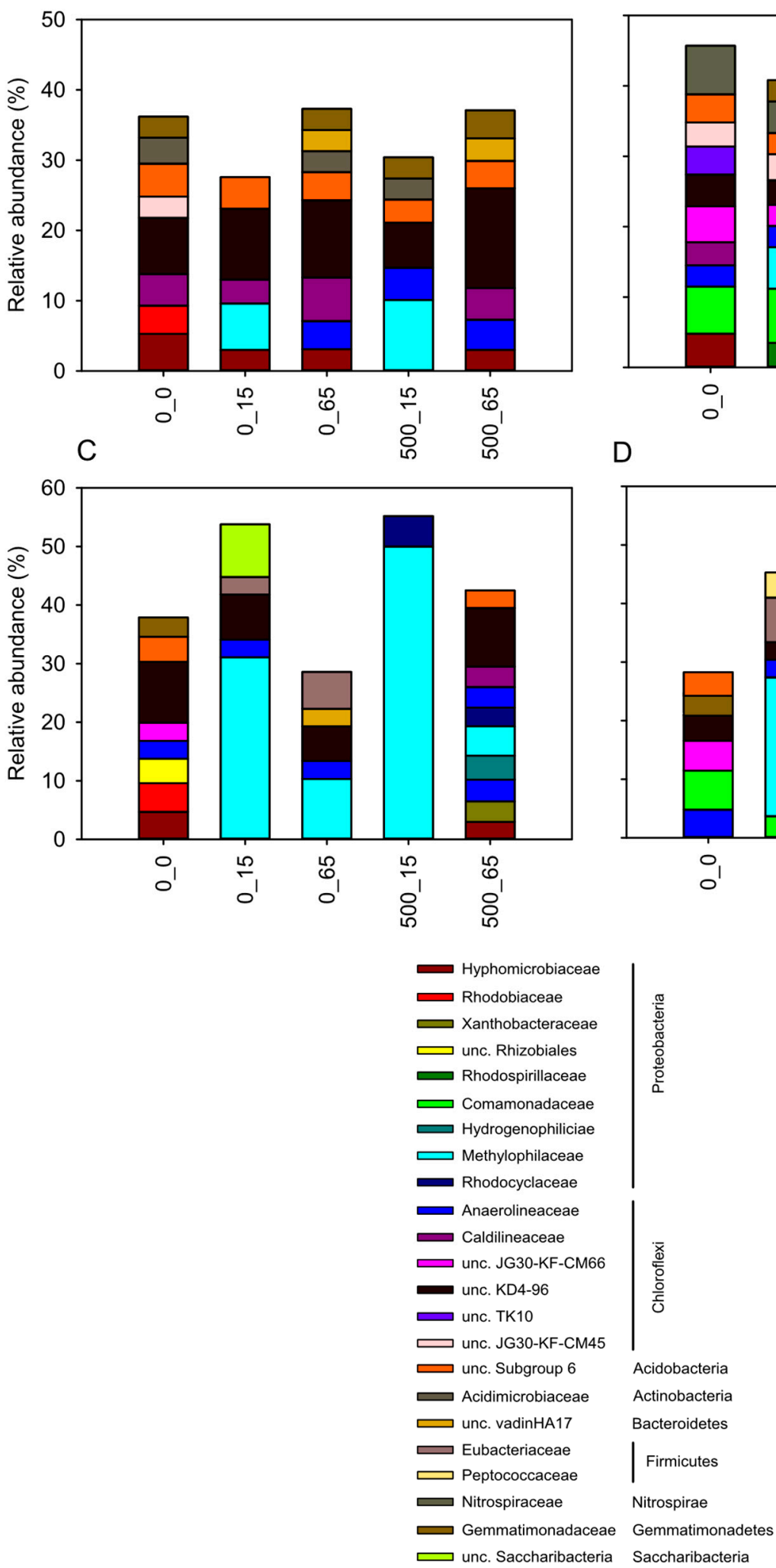

B
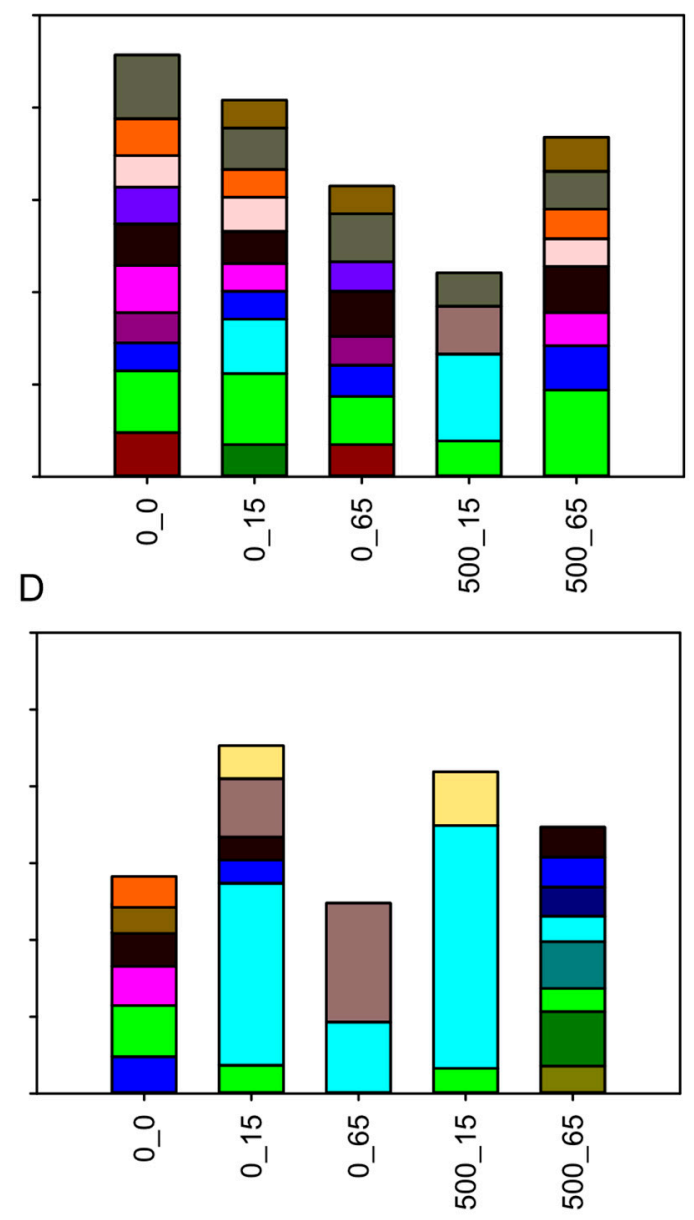
Table 1. Bacterial genus-level taxa (OTUs) enriched in TrOC-amended sediments relative to unamended controls, and closest cultured relatives of the OTU representative 16S rRNA gene sequences. Significant $(p$-adj $<0.05)$ Log2-fold changes $>0$ are reported as determined by Deseq2.

\begin{tabular}{|c|c|c|c|c|c|c|}
\hline \multirow{2}{*}{ Phylum/Sub-Phylum } & \multirow{2}{*}{ Genus-Level (OTU No.) } & \multirow{2}{*}{ Closest Cultured Relative } & \multirow{2}{*}{ Acc. $\mathrm{No}^{\mathrm{a}}$} & \multirow{2}{*}[\%]{$^{b}$} & \multicolumn{2}{|c|}{ Log2-Fold Change } \\
\hline & & & & & 16S rRNA Gene & 16S rRNA \\
\hline \multicolumn{7}{|l|}{ Proteobacteria } \\
\hline \multirow{7}{*}{ Alphaproteobacteria } & Xanthobacter (75) & Xanthobacter agilis & MK402058 & 99 & $5^{c}$ & 4 \\
\hline & Hyphomicrobium (21) & Hyphomicrobium vulgare & KC447318 & 99 & 2 & - \\
\hline & Magnetospirillum (510) & Magnetospirillum magneticum & AB983194 & 100 & $-d$ & 4 \\
\hline & Novosphingobium (120) & $\begin{array}{c}\text { Novosphingobium } \\
\text { aromaticivorans }\end{array}$ & KU924009 & 100 & - & 4 \\
\hline & Reyranella (439) & Reyranella aquatilis & NR_158037 & 100 & - & 3 \\
\hline & Rhizobium (546) & Rhizobium selenitireducens & MH665748 & 100 & - & 2 \\
\hline & Prosthecomicrobium (388) & Prosthecomicrobium hirschii & NR_104906 & 100 & - & 2 \\
\hline \multirow{3}{*}{ Deltaproteobacteria } & unc. Myxococcales (1467) & Vulgatibacter incomptus & СР012332 & 92 & 5 & 3 \\
\hline & Phaselicystis (462) & Phaselicystis flava & NR_044523 & 91 & 4 & - \\
\hline & Geothermobacter (241) & Geothermobacter ehrlichii & NR_042754 & 94 & - & 2 \\
\hline \multirow{5}{*}{ Gammaproteobacteria } & unc. Neisseriaceae (1382) & Annwoodia aquaesulis & NR_044793 & 95 & 3 & - \\
\hline & Ferritrophicum (36) & Ferritrophicum radinicola & DQ386273 & 94 & 2 & - \\
\hline & unc. Betaproteobacteriales (56) & Piscinibacter aquaticus & LC430085 & 93 & 2 & - \\
\hline & unc. Nitrosomonadaceae (77) & Collimonas fungivorans & KM604833 & 93 & 1 & - \\
\hline & Crenothrix $(268)$ & Crenothrix polyspora & DQ295898 & 96 & - & 5 \\
\hline \multicolumn{7}{|l|}{ Bacteroidetes } \\
\hline \multirow{4}{*}{ Sphingobacteriia } & unc. KD3-93 (2443) & Owenweeksia hongkongensis & СР003156 & 90 & - & 6 \\
\hline & unc. env.OPS_17 (2106) & Sphingobacterium tabacisoli & NR_159136 & 89 & - & 5 \\
\hline & unc. env.OPS_17 (818) & Anseongella ginsenosidimutans & СР042432 & 85 & - & 4 \\
\hline & Terrimonas $(370)$ & Terrimonas soli & NR_159891 & 98 & 2 & - \\
\hline Cytophagia & unc. Rhodothermaceae (1646) & Rhodothermus marinus & Y14143 & 90 & - & 2 \\
\hline
\end{tabular}

${ }^{\text {a }}$ Gene bank accession number; ${ }^{\mathrm{b}}$ similarity of OTU representative $16 \mathrm{~S}$ rRNA gene sequence to that of closest cultured relative; ${ }^{\mathrm{c}}$ significant $(p$-adj $<0.05)$ Log2-fold change $>0$ and $<0$ are reported as determined by Deseq2; ${ }^{\mathrm{d}}$ non-significant differential abundance between treatment and unamended controls. 


\section{Discussion}

\subsection{Influence of TOC on Biotransformation and Sorption of TrOCs}

Higher microbial removal efficiencies of most test compounds in the organic rich surface relative to the subsurface sediment samples (Figure 1A) highlight the significance of the organic carbon content in the removal of some micropollutants reaching the hyporheic zone. The organic carbon serves as a nutrient source for heterotrophic microorganisms and promotes bacterial colonization $[9,11,31]$. Thus, a better energy status of surface than subsurface sediment microbes might be anticipated, suggesting that surface sediment organisms are more tolerant to TrOCs and prone to respond to TrOC amendment than their subsurface sediment counterparts. This may explain the higher bacterial abundance and diversity detected in the incubated surface sediment samples (Figures 2 and 3). High diversity and abundance have been previously associated with enhanced biotransformation efficiency of many organic micropollutants [16,23,32-35], an observation the current study extends.

Acesulfame, hitherto considered persistent [36], has been recently reported to be biodegradable in constructed and natural environments, though the environmental parameters associated with these recent findings are not yet established [6,34,37]. In the current study, the biotransformation of acesulfame occurred only in the surface sediment suggesting the compound was likely degraded by specific taxa that were supported by the high TOC content in this layer compared to the subjacent layer. Benzotriazole, considered less biodegradable in WWTPs [38], was almost completely removed in the sediment samples. This may be attributed to the higher bacterial diversity and increased residence time in hyporheic zone sediments than in WWTPs $[39,40]$.

While furosemide was previously considered recalcitrant to biodegradation, biotransformation in sediments has been reported recently [41], and the current study suggests the organic carbon content may influence such biotransformation. Though the majority of previous studies reported carbamazepine as relatively persistent to biodegradation $[4,16,34,42,43]$, up to $60 \%$ removal of carbamazepine in a mixed bacterial culture has been reported [44]. In the current study, removal in the biotic microcosms was only marginally higher than in the abiotic setup suggesting possible contribution of both mechanisms in its removal as carbamazepine sorbs readily to organic matter in sediment-water systems due to its relatively high $\log D_{\text {ow }}$ of 2.8 [24].

Hydrochlorothiazide removal is attributed to photolysis and hydrolysis $[45,46]$. While photolysis can be excluded in the current study, the contribution of hydrolysis to its removal cannot be ruled out, and further investigations would be required. Indeed, hydrochlorothiazide removal was similar in biotic and abiotic treatments (Figure 1), suggesting abiotic removal mechanisms such as hydrolysis in addition to sorption as more relevant than biodegradation. Despite higher removal of clofibric acid in surface relative to subsurface sediment samples, the overall removal of the compound was still low $(<40 \%)$ in biotic microcosms under both TOC conditions suggesting the persistence of the compound in water-sediment matrices as reported in previous studies $[47,48]$. Nevertheless, biodegradation contributed to its removal (Figure 1).

The complete and near-complete removal of propranolol and metoprolol, respectively, under both TOC concentrations, matches previously reported patterns in two sediment types differing in TOC content [49]. Both compounds are structurally similar, a factor that may have influenced their similar interaction with TOC and the resident bacterial community. Since removal efficiencies in biotic and abiotic incubations were similar, abiotic mechanisms dominated biodegradation here.

On the other hand, naproxen, ibuprofen and ketoprofen (NSAIDs) exhibited variable interaction with TOC where the latter two were strongly impacted by TOC content, while naproxen was not. This may be attributed to the difference in their physical-chemical properties. While the three compounds contain the carboxyl and alkyl functional groups, naproxen differs markedly from the rest by having an ether group [50], which may account for its varied interaction with TOC or resident microbial communities. Overall, biodegradation and sorption were important removal mechanisms for the NSAIDs tested. 
Although sorption and abiotic removal mechanisms were minor compared to biotic ones for many TrOCs, a higher removal of the NSAIDs (diclofenac, ibuprofen, ketoprofen and naproxen), cholesterol-lowering agents (bezafibrate, clofibric acid), carbamazepine and benzotriazole in the surface sediment relative to subsurface sediments in abiotic microcosms indicates that sorption of these compounds is influenced by organic carbon concentration in the sediments. Such influence on sorption as a removal mechanism for some organic micropollutants in sediments by the organic matter content has been previously reported $[6,16,34,41]$. For some other compounds such as the beta-blockers (metoprolol, propranolol), furosemide and hydrochlorothiazide, no correlation with TOC concentration was observed suggesting other factors or processes contributed to their removal. Indeed, processes such as hydrolysis have been reported as significant removal mechanisms for such compounds as furosemide [51] and hydrochlorothiazide [46]. The quality of organic carbon sorbed to mineral particles or in the form of particulate organic matter likewise impacts sorption (reviewed in [52]). It is well established that the lower the $\mathrm{O} / \mathrm{C}$ ratio of such organic matter is, the higher its hydrophobicity and the higher hydrophobic interactions with dissolved organic compounds are. Organic coatings of particles are important mediators of sorption, modifying the chemical and physical properties of particles relevant for sorption, e.g., charge-distributions [53]. The contribution of such processes to their removal in the current study are thus hypothesized. Moreover, the occurrence of TrOCs in neutral and ionizable forms further determine the type of interaction with the sediment materials due to the influence of external factors such as $\mathrm{pH}$ [54]. At the prevailing $\mathrm{pH}$ in the microcosms ( $\mathrm{pH} 7.5-8)$, the test compounds potentially exhibited different physicochemical properties, and their interaction with the sediment was expected to be driven by different processes such as hydrophobic partitioning for neutral TrOCs, e.g., carbamazepine, and electrostatic interactions and surface complexation for the ionizable TrOCs, e.g., ibuprofen, naproxen, ketoprofen and diclofenac [6,55]. In the same way, desorption of the TrOCs from the sediment into the aqueous phase may be driven by the same factors leading to a counteractive effect on the sorption as a TrOC removal mechanism.

\subsection{Interplay of TOC, Bacterial Community Structure and TrOC Removal}

The difference in the organic carbon content in the two sediment samples was reflected in the bacterial community structure and TrOC removal dynamics. The taxonomic composition of the bacterial community at the phylum level remained relatively constant throughout the incubation in the surface sediment samples (Figure 5A,B), likely due to the stable supply of carbon and energy from the organic-rich sediment. In the presence of abundant primary carbon sources, degradation of TrOCs via cometabolism as previously demonstrated appears likely [6]. In such a scenario, the bacteria possibly utilized the organic carbon as the sole source of carbon and energy while transforming the TrOCs as a non-growth substrate [56]. While cometabolism is a major TrOC removal mechanism in cases where the concentration of the TrOCs is too low to support biomass growth, or where they exhibit apparent toxicity rendering them unfavorable to enter catabolic pathways of microbial cells, in some cases the cometabolism initiates a reaction to transform persistent compounds into their more biodegradable forms before they enter the central metabolic pathways [40]. The latter may have occurred as reflected in the marginal increase in the relative abundances of Proteobacteria, Bacteroidetes, Firmicutes, Acidobacteria, Chloroflexi and Gemmatimonadetes in amended relative to unamended samples (Figure 5A,B), indicating potential utilization of some of the TrOCs as a carbon source by these phyla. However, metabolic degradation cannot be excluded and might represent an alternative explanation for such findings. Indeed, members belonging to these phyla have been associated with degradation of various xenobiotics including the current test compounds $[16,23,24,57-62]$.

In the subsurface sediment samples, a shift in the bacterial community composition in the amended samples relative to unamended controls at day 15 of incubation (Figure 5C,D), in which the relative abundance of Proteobacteria increased, while other phyla such as Chloroflexi, Firmicutes and Actinobacteria declined, suggested a possible change in the carbon utilization dynamics. Depletion of readily degradable organic carbon may have favored Proteobacteria. As relatively rapid responders to 
substrates [63], and a characteristic broad physiological and metabolic diversity [64], the Proteobacteria may have easily adapted to utilizing the TrOCs as an alternative sole carbon and energy source, hence outcompeting the other taxa in the microbial community. Nevertheless, analyses at the family and genus levels revealed that even within the declining phyla some taxa increased in their relative abundance in amended relative to unamended samples, thus suggesting a possible utilization of TrOCs as a carbon source. (Figure 6C,D; Table 1). Such a phenomenon with different members of the same phylum responding differently to TrOC exposure has been previously reported $[16,23,65]$. Slow responders such as Chloroflexi and Acidobacteria were only observed to increase in relative abundance at day 65 , signifying the importance of contact time between some bacterial groups and TrOCs, a factor associated with the enhanced TrOC removal capacity of hyporheic zone sediments compared to WWTPs $[15,23,39]$.

\subsection{Putative Taxa Associated with Degradation of the Test Compounds}

Bacterial taxa enriched in the micropollutant-amended microcosms relative to the unamended controls were considered potential degraders of the test compounds (Figure 6; Table 1). These included Proteobacteria affiliated families Methylophilaceae, whose members are obligate methylotrophs but were also previously associated with the degradation of TrOCs such as ketoprofen, formononetin, ibuprofen, primidone, ametrine and naproxen [66] as well as Comamonadaceae previously associated with the degradation of pharmaceuticals in sediments $[16,23]$. The relative enrichment in the current study of Rhodocyclaceae, hitherto associated with anaerobic hydrocarbon degradation, extends on the recently reported potential of some Rhodocyclaceae affiliated taxa to degrade hydrocarbons under oxic conditions [67]. Rhodocyclaceae was also important for the degradation of toluene under oxygen-limiting conditions [67], highlighting potential resilience in the hyporheic zone under declining oxygen conditions. This may explain its flourishing in the subsurface sediment samples where oxygen availability may be limited (Figure 6C,D). The potential of Rhodospirillaceae and Xanthomonadaceae in the degradation of aromatic organic compounds is widely reported [23,68-71]. Their relative enrichment by TrOCs in the present study, therefore, extends this observation.

Enriched taxa at the genus level included the toluene-degrading Xanthobacter [72], Hyphomicrobium previously associated with the degradation of ibuprofen [23] and 2,4-Dichlorophenol [73], Novosphingobium widely associated with the degradation of numerous aromatic compounds including pharmaceuticals $[16,23,24,61]$, and Rhizobium enriched in ibuprofen-amended sediment samples [23]. Other Proteobacteria affiliated genera hitherto unassociated with xenobiotic degradation but enriched in the TrOC-amended samples included Phaselicystis, Ferritrophicum, Crenothrix, Magnetospirillum, Reyranella, Prosthecomicrobium and Geothermobacter, suggesting their involvement in the biotransformation of the test compounds. The genus Terrimonas belonging to the Bacteroidetes was previously associated with the degradation of ibuprofen [23], dibutyl phthalate [74] and benzo[a]pyrene [75], and was also enriched by the test compounds in the current study.

The increase in the relative abundance of Chloroflexi affiliated Caldilinaceae and Anaerolineaceae following TrOC amendment corresponds to the previous association of these families with TrOC removal $[66,76]$. The Caldilinaceae affiliated genus Caldilinea was previously associated with TrOC removal in an anoxic-aerobic membrane bioreactor [66], while Anaerolineaceae representatives were associated with degradation of organic pollutants, aromatics and n-alkanes under anaerobic conditions [76-78]. Although considered strictly anaerobic [79], a surprisingly considerable abundance of Anaerolineaceae members was detected in aerobic WWTP water samples [78]. The authors attributed the observation to the presence of anoxic microzones within the aerated wastewater flocs. A recent study further revealed enrichment of Anaerolineaceae in ibuprofen-amended oxic hyporheic zone sediments [23]. Their prevalence in such conditions may, therefore, be attributed to similar anoxic microzones commonly reported within the oxic hyporheic zone sediments [15]. The enrichment of the Chloroflexi affiliated unclassified KD4-96 and JG30-KF-CM45 families in the current study further 
extends their association with the degradation of TrOCs as recently reported in ibuprofen-amended oxic hyporheic zone sediments [23].

An unclassified Acidobacteria Subgroup 6 family enriched in the presence of TrOCs is in agreement with the reported association of members within this phylum with the degradation of pharmaceuticals, polychlorinated biphenyls and petroleum compounds $[16,23,57,80]$. The family Acidimicrobiaceae has been associated with ibuprofen degradation in oxic hyporheic zone sediments [23], and its enrichment in the current study suggests a potential to degrade aromatic compounds. The increase in the relative abundance of Gemmatimonadaceae in amended relative to unamended sediment samples suggests the potential to utilize at least some of the TrOCs. Members of this family have been associated with degradation of ibuprofen [23] and other complex compounds, e.g., the benzoate-degrading Gemmatimonas aurantiaca and an uncultured Gemmatimonas species were associated with alkylbenzene sulfonate degradation [60].

The enrichment of Firmicutes affiliated Eubacteriaceae and Peptococcaceae belonging to Clostridia corresponds to their previous association with xenobiotic degradation. Eubacteriaceae was among soil microorganisms associated with soils historically contaminated by heavy metals and hydrocarbons [81]. Peptococcaceae, though previously reported in the anaerobic degradation of aromatic compounds [82], have been recently shown to harbor genes encoding enzymes involved in benzene degradation in a benzene-degrading denitrifying continuous culture, where transcripts associated with the family Peptococcaceae dominated all samples [83]. The enrichment of such a broad range of taxa by TrOCs in hyporheic sediments highlights the hyporheic zone as a reservoir of diverse bacteria with a potential to degrade a wide range of emerging contaminants.

\section{Conclusions}

Though the microbial removal efficiency of most TrOCs declined with increasing hyporheic sediment depth attributable to the differences in the concentration of organic carbon and associated changes in microbial community dynamics, in some cases, low concentrations of organic carbon can boost TrOC removal, since in high concentrations, the organic carbon may also serve as a competitive substrate that inhibits preferential degradation of TrOCs. As evidenced in the current study, the contribution of sorption and other abiotic removal mechanisms to the fate of organic micropollutants in sediment-water matrices is not to be ignored. Moreover, the contribution of the biotic and abiotic processes in TrOC removal is not exclusionary but rather complementary since, for example, sorption may impair or enhance the bioavailability of a compound. Likewise, biodegradation of dissolved compounds at equilibrium concentrations will stimulate desorption of sorbed fractions. Thus, the importance of biodegradation might be underestimated when abiotic and biotic treatments are merely compared in terms of TrOC removal.

The bacterial community analyses in TrOC amended relative to unamended sediment samples highlight diverse bacteria potentially supporting TrOC removal, a remarkable tolerance of hyporheic zone bacterial taxa towards a cocktail of TrOCs at rather high concentrations, and how environmental factors such as TOC might impact TrOC removal. Thus, the hyporheic zone supports an important ecosystem service in terms of sustaining a diverse microbiome and surfaces for microbial colonization as well as TrOC sorption, all contributing to the removal of TrOCs from river water.

Author Contributions: Conceptualization, C.R. and M.P.; methodology, C.R. and M.P.; software, C.R. and M.P.; validation, C.R., M.P. and M.A.H.; formal analysis, C.R. and M.P.; investigation, C.R. and M.P.; resources, C.R., M.P. and M.A.H.; data curation, C.R. and M.P.; writing-original draft preparation, C.R.; writing-review and editing, C.R., M.P. and M.A.H.; visualization, C.R. and M.P.; supervision, M.A.H.; project administration, M.A.H.; funding acquisition, M.A.H. All authors have read and agreed to the published version of the manuscript.

Funding: This research was funded by the European Union's Horizon 2020 research and innovation program under the Marie Sklodowska-Curie-grant agreement No. 641939. Partial funding was also provided by the Leibniz University Hannover, Germany.

Acknowledgments: The authors thank Jon Benskin for providing useful suggestions that improved the original manuscript. 
Conflicts of Interest: The authors declare no conflict of interest. The funders had no role in the design of the study; in the collection, analyses, or interpretation of data; in the writing of the manuscript, or in the decision to publish the results.

\section{References}

1. Eggen, R.I.L.; Hollender, J.; Joss, A.; Schärer, M.; Stamm, C. Reducing the Discharge of Micropollutants in the Aquatic Environment: The Benefits of Upgrading Wastewater Treatment Plants; ACS Publications: Washington, DC, USA, 2014.

2. Lewandowski, J.; Putschew, A.; Schwesig, D.; Neumann, C.; Radke, M. Fate of Organic Micropollutants in the Hyporheic Zone of a Eutrophic Lowland Stream: Results of a Preliminary Field Study. Sci. Total Environ. 2011, 409, 1824-1835. [CrossRef] [PubMed]

3. Pal, A.; He, Y.; Jekel, M.; Reinhard, M.; Gin, K.Y.-H. Emerging Contaminants of Public Health Significance as Water Quality Indicator Compounds in the Urban Water Cycle. Environ. Int. 2014, 71, 46-62. [CrossRef] [PubMed]

4. Posselt, M.; Jaeger, A.; Schaper, J.L.; Radke, M.; Benskin, J.P. Determination of Polar Organic Micropollutants in Surface and Pore Water by High-Resolution Sampling-Direct Injection-Ultra High Performance Liquid Chromatography-Tandem Mass Spectrometry. Environ. Sci. Process. Impacts 2018, 20, 1716-1727. [CrossRef] [PubMed]

5. Mechelke, J.; Vermeirssen, E.L.M.; Hollender, J. Passive Sampling of Organic Contaminants across the Water-Sediment Interface of an Urban Stream. Water Res. 2019, 165, 114966. [CrossRef]

6. Schaper, J.L.; Posselt, M.; Bouchez, C.; Jaeger, A.; Nuetzmann, G.; Putschew, A.; Singer, G.; Lewandowski, J. Fate of Trace Organic Compounds in the Hyporheic Zone: Influence of Retardation, the Benthic Biolayer, and Organic Carbon. Environ. Sci. Technol. 2019, 53, 4224-4234. [CrossRef]

7. Atashgahi, S.; Aydin, R.; Dimitrov, M.R.; Sipkema, D.; Hamonts, K.; Lahti, L.; Maphosa, F.; Kruse, T.; Saccenti, E.; Springael, D. Impact of a Wastewater Treatment Plant on Microbial Community Composition and Function in a Hyporheic Zone of a Eutrophic River. Sci. Rep. 2015, 5, 17284. [CrossRef]

8. Tülp, H.C.; Fenner, K.; Schwarzenbach, R.P.; Goss, K.-U. PH-Dependent Sorption of Acidic Organic Chemicals to Soil Organic Matter. Environ. Sci. Technol. 2009, 43, 9189-9195. [CrossRef]

9. Romani, A.M.; Butturini, A.; Sabater, F.; Sabater, S. Heterotrophic Metabolism in a Forest Stream Sediment: Surface versus Subsurface Zones. Aquat. Microb. Ecol. 1998, 16, 143-151. [CrossRef]

10. Gücker, B.; Brauns, M.; Pusch, M.T. Effects of Wastewater Treatment Plant Discharge on Ecosystem Structure and Function of Lowland Streams. J. North Am. Benthol. Soc. 2006, 25, 313-329. [CrossRef]

11. Findlay, S. Microbial Communities in Hyporheic Sediments. Streams Gr. Waters 2000, 287-306.

12. Baschien, C.; Manz, W.; Neu, T.R.; Marvanová, L.; Szewzyk, U. In Situ Detection of Freshwater Fungi in an Alpine Stream by New Taxon-Specific Fluorescence in Situ Hybridization Probes. Appl. Environ. Microbiol. 2008, 74, 6427-6436. [CrossRef] [PubMed]

13. Battin, T.J.; Besemer, K.; Bengtsson, M.M.; Romani, A.M.; Packmann, A.I. The Ecology and Biogeochemistry of Stream Biofilms. Nat. Rev. Microbiol. 2016, 14, 251. [CrossRef] [PubMed]

14. Buriánková, I.; Brablcová, L.; Mach, V.; Dvořák, P.; Chaudhary, P.P.; Rulík, M. Identification of Methanogenic Archaea in the Hyporheic Sediment of Sitka Stream. PLoS ONE 2013, 8, e80804. [CrossRef] [PubMed]

15. Lewandowski, J.; Arnon, S.; Banks, E.; Batelaan, O.; Betterle, A.; Broecker, T.; Coll, C.; Drummond, J.D.; Garcia, J.G.; Galloway, J.; et al. Is the Hyporheic Zone Relevant beyond the Scientific Community? Water 2019, 11, 2230. [CrossRef]

16. Posselt, M.; Mechelke, J.; Rutere, C.; Coll, C.; Jaeger, A.; Raza, M.; Meinikmann, K.; Krause, S.; Sobek, A.; Lewandowski, J.; et al. Bacterial Diversity Controls Transformation of Wastewater-Derived Organic Contaminants in River-Simulating Flumes. Environ. Sci. Technol. 2020, 54, 5467-5479. [CrossRef]

17. Wellsbury, P.; Herbert, R.A.; Parkes, R.J. Bacterial Activity and Production in Near-Surface Estuarine and Freshwater Sediments. FEMS Microbiol. Ecol. 1996, 19, 203-214. [CrossRef]

18. Harvey, J.W.; Böhlke, J.K.; Voytek, M.A.; Scott, D.; Tobias, C.R. Hyporheic Zone Denitrification: Controls on Effective Reaction Depth and Contribution to Whole-stream Mass Balance. Water Resour. Res. 2013, 49, 6298-6316. [CrossRef] 
19. Knapp, J.L.A.; González-Pinzón, R.; Drummond, J.D.; Larsen, L.G.; Cirpka, O.A.; Harvey, J.W. Tracer-based Characterization of Hyporheic Exchange and Benthic Biolayers in Streams. Water Resour. Res. 2017, 53, 1575-1594. [CrossRef]

20. Jaeger, A.; Posselt, M.; Betterle, A.; Schaper, J.; Mechelke, J.; Coll, C.; Lewandowski, J. Spatial and Temporal Variability in Attenuation of Polar Organic Micropollutants in an Urban Lowland Stream. Environ. Sci. Technol. 2019, 53, 2383-2395. [CrossRef]

21. Peralta-Maraver, I.; Galloway, J.; Posselt, M.; Arnon, S.; Reiss, J.; Lewandowski, J.; Robertson, A.L. Environmental Filtering and Community Delineation in the Streambed Ecotone. Sci. Rep. 2018, 8, 1-11. [CrossRef]

22. Crawford, J.T.; Stanley, E.H. Controls on Methane Concentrations and Fluxes in Streams Draining Human-dominated Landscapes. Ecol. Appl. 2016, 26, 1581-1591. [CrossRef] [PubMed]

23. Rutere, C.; Knoop, K.; Posselt, M.; Ho, A.; Horn, M.A. Ibuprofen Degradation and Associated Bacterial Communities in Hyporheic Zone Sediments. Microorganisms 2020, 8, 1245. [CrossRef] [PubMed]

24. Coll, C.; Bier, R.; Li, Z.; Langenheder, S.; Gorokhova, E.; Sobek, A. Association between Aquatic Micropollutant Dissipation and River Sediment Bacterial Communities. Environ. Sci. Technol. 2020, 54, 14380-14392. [CrossRef] [PubMed]

25. Griffiths, R.I.; Whiteley, A.S.; O’Donnell, A.G.; Bailey, M.J. Rapid Method for Coextraction of DNA and RNA from Natural Environments for Analysis of Ribosomal DNA-and RRNA-Based Microbial Community Composition. Appl. Environ. Microbiol. 2000, 66, 5488-5491. [CrossRef] [PubMed]

26. Zaprasis, A.; Liu, Y.-J.; Liu, S.-J.; Drake, H.L.; Horn, M.A. Abundance of Novel and Diverse TfdA-like Genes, Encoding Putative Phenoxyalkanoic Acid Herbicide-Degrading Dioxygenases, in Soil. Appl. Environ. Microbiol. 2010, 76, 119-128. [CrossRef]

27. Sundberg, C.; Al-Soud, W.A.; Larsson, M.; Alm, E.; Yekta, S.S.; Svensson, B.H.; Sørensen, S.J.; Karlsson, A. 454 Pyrosequencing Analyses of Bacterial and Archaeal Richness in 21 Full-Scale Biogas Digesters. FEMS Microbiol. Ecol. 2013, 85, 612-626. [CrossRef] [PubMed]

28. Schloss, P.D.; Westcott, S.L.; Ryabin, T.; Hall, J.R.; Hartmann, M.; Hollister, E.B.; Lesniewski, R.A.; Oakley, B.B.; Parks, D.H.; Robinson, C.J. Introducing Mothur: Open-Source, Platform-Independent, Community-Supported Software for Describing and Comparing Microbial Communities. Appl. Environ. Microbiol. 2009, 75, 7537-7541. [CrossRef]

29. Hammer, Ø.; Harper, D.A.T.; Ryan, P.D. PAST: Paleontological Statistics Software Package for Education and Data Analysis. Palaeontol. Electron. 2001, 4, 9.

30. Love, M.; Anders, S.; Huber, M. Differential Gene Expression Analysis Based on the Negative Binomial Distribution. Genome Biol. 2014, 15, 550. [CrossRef]

31. Marxsen, J. Measurement of Bacterial Production in Stream-Bed Sediments via Leucine Incorporation. FEMS Microbiol. Ecol. 1996, 21, 313-325. [CrossRef]

32. Johnson, D.R.; Helbling, D.E.; Lee, T.K.; Park, J.; Fenner, K.; Kohler, H.-P.E.; Ackermann, M. Association of Biodiversity with the Rates of Micropollutant Biotransformations among Full-Scale Wastewater Treatment Plant Communities. Appl. Environ. Microbiol. 2015, 81, 666-675. [CrossRef]

33. Stadler, L.B.; Delgado Vela, J.; Jain, S.; Dick, G.J.; Love, N.G. Elucidating the Impact of Microbial Community Biodiversity on Pharmaceutical Biotransformation during Wastewater Treatment. Microb. Biotechnol. 2018, 11, 995-1007. [CrossRef]

34. Jaeger, A.; Coll, C.; Posselt, M.; Mechelke, J.; Rutere, C.; Betterle, A.; Raza, M.; Mehrtens, A.; Meinikmann, K.; Portmann, A.; et al. Using Recirculating Flumes and a Response Surface Model to Investigate the Role of Hyporheic Exchange and Bacterial Diversity on Micropollutant Half-Lives. Environ. Sci. Process. Impacts 2019, 21, 2093-2108. [CrossRef]

35. Mechelke, J.; Rust, D.; Jaeger, A.; Hollender, J. Enantiomeric Fractionation during Biotransformation of Chiral Pharmaceuticals in Recirculating Water-Sediment Test Flumes. Environ. Sci. Technol. 2020, 54, 7291-7301. [CrossRef]

36. Buerge, I.J.; Buser, H.-R.; Kahle, M.; Muller, M.D.; Poiger, T. Ubiquitous Occurrence of the Artificial Sweetener Acesulfame in the Aquatic Environment: An Ideal Chemical Marker of Domestic Wastewater in Groundwater. Environ. Sci. Technol. 2009, 43, 4381-4385. [CrossRef] 
37. Kahl, S.; Kleinsteuber, S.; Nivala, J.; van Afferden, M.; Reemtsma, T. Emerging Biodegradation of the Previously Persistent Artificial Sweetener Acesulfame in Biological Wastewater Treatment. Environ. Sci. Technol. 2018, 52, 2717-2725. [CrossRef]

38. Giger, W.; Schaffner, C.; Kohler, H.-P.E. Benzotriazole and Tolyltriazole as Aquatic Contaminants. 1. Input and Occurrence in Rivers and Lakes. Environ. Sci. Technol. 2006, 40, 7186-7192. [CrossRef]

39. Peralta-Maraver, I.; Reiss, J.; Robertson, A.L. Interplay of Hydrology, Community Ecology and Pollutant Attenuation in the Hyporheic Zone. Sci. Total Environ. 2018, 610-611, 267-275. [CrossRef]

40. Tran, N.H.; Urase, T.; Ngo, H.H.; Hu, J.; Ong, S.L. Insight into Metabolic and Cometabolic Activities of Autotrophic and Heterotrophic Microorganisms in the Biodegradation of Emerging Trace Organic Contaminants. Bioresour. Technol. 2013, 146, 721-731. [CrossRef]

41. Liu, F.; Nielsen, A.H.; Vollertsen, J. Sorption and Degradation Potential of Pharmaceuticals in Sediments from a Stormwater Retention Pond. Water 2019, 11, 526. [CrossRef]

42. Burke, V.; Schneider, L.; Greskowiak, J.; Zerball-van Baar, P.; Sperlich, A.; Dünnbier, U.; Massmann, G. Trace Organic Removal during River Bank Filtration for Two Types of Sediment. Water 2018, 10, 1736. [CrossRef]

43. Coll, C.; Lindim, C.; Sobek, A.; Sohn, M.D.; MacLeod, M. Prospects for Finding Junge Variability-Lifetime Relationships for Micropollutants in the Danube River. Environ. Sci. Process. Impacts 2019, 21, 1489-1497. [CrossRef] [PubMed]

44. Ha, H.; Mahanty, B.; Yoon, S.; Kim, C.-G. Degradation of the Long-Resistant Pharmaceutical Compounds Carbamazepine and Diatrizoate Using Mixed Microbial Culture. J. Environ. Sci. Health Part A 2016, 51, 467-471. [CrossRef]

45. Brigante, M.; DellaGreca, M.; Previtera, L.; Rubino, M.; Temussi, F. Degradation of Hydrochlorothiazide in Water. Environ. Chem. Lett. 2005, 2, 195-198. [CrossRef]

46. Li, Z.; Maier, M.P.; Radke, M. Screening for Pharmaceutical Transformation Products Formed in River Sediment by Combining Ultrahigh Performance Liquid Chromatography/High Resolution Mass Spectrometry with a Rapid Data-Processing Method. Anal. Chim. Acta 2014, 810, 61-70. [CrossRef]

47. Kunkel, U.; Radke, M. Biodegradation of Acidic Pharmaceuticals in Bed Sediments: Insight from a Laboratory Experiment. Environ. Sci. Technol. 2008, 42, 7273-7279. [CrossRef]

48. Löffler, D.; Römbke, J.; Meller, M.; Ternes, T.A. Environmental Fate of Pharmaceuticals in Water/Sediment Systems. Environ. Sci. Technol. 2005, 39, 5209-5218. [CrossRef]

49. Ramil, M.; El Aref, T.; Fink, G.; Scheurer, M.; Ternes, T.A. Fate of Beta Blockers in Aquatic-Sediment Systems: Sorption and Biotransformation. Environ. Sci. Technol. 2010, 44, 962-970. [CrossRef]

50. Ashe, B.; Nguyen, L.N.; Hai, F.I.; Lee, D.-J.; Van De Merwe, J.P.; Leusch, F.D.L.; Price, W.E.; Nghiem, L.D. Impacts of Redox-Mediator Type on Trace Organic Contaminants Degradation by Laccase: Degradation Efficiency, Laccase Stability and Effluent Toxicity. Int. Biodeterior. Biodegrad. 2016, 113, 169-176. [CrossRef]

51. Yagi, N.; Kenmotsu, H.; Sekikawa, H.; Takada, M. Studies on the Photolysis and Hydrolysis of Furosemide in Aqueous Solution. Chem. Pharm. Bull. 1991, 39, 454-457. [CrossRef]

52. Huang, W.; Peng, P.; Yu, Z.; Fu, J. Effects of Organic Matter Heterogeneity on Sorption and Desorption of Organic Contaminants by Soils and Sediments. Appl. Geochem. 2003, 18, 955-972. [CrossRef]

53. Fer, M.; Kodešová, R.; Golovko, O.; Schmidtová, Z.; Klement, A.; Nikodem, A.; Kočárek, M.; Grabic, R. Sorption of Atenolol, Sulfamethoxazole and Carbamazepine onto Soil Aggregates from the Illuvial Horizon of the Haplic Luvisol on Loess. Soil Water Res. 2018, 13, 177-183. [CrossRef]

54. Schwarzenbach, R.P. Sorption Behavior of Neutral and Ionizable Hydrophobic Organic Compounds. In Organic Micropollutants in the Aquatic Environment; Springer: Berlin/Heidelberg, Germany, 1986; pp. $168-177$.

55. Fujioka, T.; Khan, S.J.; McDonald, J.A.; Nghiem, L.D. Rejection of Trace Organic Chemicals by a Hollow Fibre Cellulose Triacetate Reverse Osmosis Membrane. Desalination 2015, 368, 69-75. [CrossRef]

56. Arp, D.J.; Yeager, C.M.; Hyman, M.R. Molecular and Cellular Fundamentals of Aerobic Cometabolism of Trichloroethylene. Biodegradation 2001, 12, 81-103. [CrossRef]

57. Nogales, B.; Moore, E.R.B.; Abraham, W.; Timmis, K.N. Identification of the Metabolically Active Members of a Bacterial Community in a Polychlorinated Biphenyl-polluted Moorland Soil. Environ. Microbiol. 1999, 1, 199-212. [CrossRef]

58. Seo, J.-S.; Keum, Y.-S.; Li, Q.X. Bacterial Degradation of Aromatic Compounds. Int. J. Environ. Res. Public Health 2009, 6, 278-309. [CrossRef] 
59. Gargouri, B.; Karray, F.; Mhiri, N.; Aloui, F.; Sayadi, S. Bioremediation of Petroleum Hydrocarbons-contaminated Soil by Bacterial Consortium Isolated from an Industrial Wastewater Treatment Plant. J. Chem. Technol. Biotechnol. 2014, 89, 978-987. [CrossRef]

60. Braga, J.K.; Motteran, F.; Silva, E.L.; Varesche, M.B.A. Evaluation of Bacterial Community from Anaerobic Fluidized Bed Reactor for the Removal of Linear Alkylbenzene Sulfonate from Laundry Wastewater by 454-Pyrosequence. Ecol. Eng. 2015, 82, 231-240. [CrossRef]

61. Ghosal, D.; Ghosh, S.; Dutta, T.K.; Ahn, Y. Current State of Knowledge in Microbial Degradation of Polycyclic Aromatic Hydrocarbons (PAHs): A Review. Front. Microbiol. 2016, 7, 1369. [CrossRef]

62. Nasir, N.M.; Talib, S.A.; Hashim, S.N.; Tay, C.C. Biodegradation of Carbamazepine Using Fungi and Bacteria. J. Fundam. Appl. Sci. 2018, 9, 124. [CrossRef]

63. Ho, A.; Di Lonardo, D.P.; Bodelier, P.L.E. Revisiting Life Strategy Concepts in Environmental Microbial Ecology. FEMS Microbiol. Ecol. 2017, 93, fix006. [CrossRef] [PubMed]

64. Harichová, J.; Karelová, E.; Pangallo, D.; Ferianc, P. Structure Analysis of Bacterial Community and Their Heavy-Metal Resistance Determinants in the Heavy-Metal-Contaminated Soil Sample. Biologia 2012, 67, 1038-1048. [CrossRef]

65. Lawrence, J.R.; Swerhone, G.D.W.; Wassenaar, L.I.; Neu, T.R. Effects of Selected Pharmaceuticals on Riverine Biofilm Communities. Can. J. Microbiol. 2005, 51, 655-669. [CrossRef] [PubMed]

66. Phan, H.V.; Hai, F.I.; Zhang, R.; Kang, J.; Price, W.E.; Nghiem, L.D. Bacterial Community Dynamics in an Anoxic-Aerobic Membrane Bioreactor-Impact on Nutrient and Trace Organic Contaminant Removal. Int. Biodeterior. Biodegrad. 2016, 109, 61-72. [CrossRef]

67. Táncsics, A.; Szalay, A.R.; Farkas, M.; Benedek, T.; Szoboszlay, S.; Szabó, I.; Lueders, T. Stable Isotope Probing of Hypoxic Toluene Degradation at the Siklós Aquifer Reveals Prominent Role of Rhodocyclaceae. FEMS Microbiol. Ecol. 2018, 94, fiy088. [CrossRef]

68. Gibson, J.; Harwood, C.S. Degradation of Aromatic Compounds by Nonsulfur Purple Bacteria. In Anoxygenic Photosynthetic Bacteria; Springer: Berlin/Heidelberg, Germany, 1995; pp. 991-1003.

69. Wang, L.; Zheng, S.; Wang, D.; Wang, L.; Wang, G. Thermomonas Carbonis Sp. Nov., Isolated from the Soil of a Coal Mine. Int. J. Syst. Evol. Microbiol. 2014, 64, 3631-3635. [CrossRef]

70. Brzeszcz, J.; Kaszycki, P. Aerobic Bacteria Degrading Both N-Alkanes and Aromatic Hydrocarbons: An Undervalued Strategy for Metabolic Diversity and Flexibility. Biodegradation 2018, 29, 359-407. [CrossRef]

71. Cydzik-Kwiatkowska, A.; Zielińska, M. Microbial Composition of Biofilm Treating Wastewater Rich in Bisphenol A. J. Environ. Sci. Health Part A 2018, 53, 385-392. [CrossRef]

72. Tay, S.T.-L.; Hemond, H.F.; Polz, M.F.; Cavanaugh, C.M.; Krumholz, L.R. Importance of Xanthobacter Autotrophicus in Toluene Biodegradation within a Contaminated Stream. Syst. Appl. Microbiol. 1999, 22, 113-118. [CrossRef]

73. Dallinger, A.; Horn, M.A. Agricultural Soil and Drilosphere as Reservoirs of New and Unusual Assimilators of 2, 4-dichlorophenol Carbon. Environ. Microbiol. 2014, 16, 84-100. [CrossRef]

74. Jin, D.; Wang, P.; Bai, Z.; Jin, B.; Yu, Z.; Wang, X.; Zhuang, G.; Zhang, H. Terrimonas pekingensis sp. nov., Isolated from Bulking Sludge, and Emended Descriptions of the Genus Terrimonas, Terrimonas ferruginea, Terrimonas lutea and Terrimonas aquatica. Int. J. Syst. Evol. Microbiol. 2013, 63, 1658-1664. [CrossRef] [PubMed]

75. Song, M.; Luo, C.; Jiang, L.; Zhang, D.; Wang, Y.; Zhang, G. Identification of Benzo [a] Pyrene-Metabolizing Bacteria in Forest Soils by Using DNA-Based Stable-Isotope Probing. Appl. Environ. Microbiol. 2015, 81, 7368-7376. [CrossRef] [PubMed]

76. Miettinen, H.; Bomberg, M.; Nyyssönen, M.; Reunamo, A.; Jørgensen, K.S.; Vikman, M. Oil Degradation Potential of Microbial Communities in Water and Sediment of Baltic Sea Coastal Area. PLoS ONE 2019, 14, e0218834. [CrossRef] [PubMed]

77. Kümmel, S.; Herbst, F.-A.; Bahr, A.; Duarte, M.; Pieper, D.H.; Jehmlich, N.; Seifert, J.; von Bergen, M.; Bombach, P.; Richnow, H.H. Anaerobic Naphthalene Degradation by Sulfate-Reducing Desulfobacteraceae from Various Anoxic Aquifers. FEMS Microbiol. Ecol. 2015, 91. [CrossRef] [PubMed]

78. Chen, Y.; Zhao, Z.; Peng, Y.; Li, J.; Xiao, L.; Yang, L. Performance of a Full-Scale Modified Anaerobic/Anoxic/Oxic Process: High-Throughput Sequence Analysis of Its Microbial Structures and Their Community Functions. Bioresour. Technol. 2016, 220, 225-232. [CrossRef] 
79. Zhang, B.; Yu, Q.; Yan, G.; Zhu, H.; Yang Xu, X.; Zhu, L. Seasonal Bacterial Community Succession in Four Typical Wastewater Treatment Plants: Correlations between Core Microbes and Process Performance. Sci. Rep. 2018, 8, 1-11. [CrossRef]

80. George, I.F.; Liles, M.R.; Hartmann, M.; Ludwig, W.; Goodman, R.M.; Agathos, S.N. Changes in Soil Acidobacteria Communities after 2, 4, 6-Trinitrotoluene Contamination. FEMS Microbiol. Lett. 2009, 296, 159-166. [CrossRef]

81. Vivas, A.; Moreno, B.; del Val, C.; Macci, C.; Masciandaro, G.; Benitez, E. Metabolic and Bacterial Diversity in Soils Historically Contaminated by Heavy Metals and Hydrocarbons. J. Environ. Monit. 2008, 10, 1287-1296. [CrossRef]

82. Kuppardt, A.; Kleinsteuber, S.; Vogt, C.; Lüders, T.; Harms, H.; Chatzinotas, A. Phylogenetic and Functional Diversity within Toluene-Degrading, Sulphate-Reducing Consortia Enriched from a Contaminated Aquifer. Microb. Ecol. 2014, 68, 222-234. [CrossRef]

83. Atashgahi, S.; Hornung, B.; Van Der Waals, M.J.; Da Rocha, U.N.; Hugenholtz, F.; Nijsse, B.; Molenaar, D.; Van Spanning, R.; Stams, A.J.M.; Gerritse, J. A Benzene-Degrading Nitrate-Reducing Microbial Consortium Displays Aerobic and Anaerobic Benzene Degradation Pathways. Sci. Rep. 2018, 8, 1-12. [CrossRef]

Publisher's Note: MDPI stays neutral with regard to jurisdictional claims in published maps and institutional affiliations.

(C) 2020 by the authors. Licensee MDPI, Basel, Switzerland. This article is an open access article distributed under the terms and conditions of the Creative Commons Attribution (CC BY) license (http://creativecommons.org/licenses/by/4.0/). 